\title{
Teaching and learning in the knowledge society
}

\author{
Dr Beatriz Fainholc \\ Universidad Nacional de La Plata, Argentina
}

\begin{abstract}
The education processes within the knowledge society of the twenty-first century involve a complex analysis and transformation of learning and teaching proposals. The ubiquitous penetration of technology and especially of ICT contributes to new cultural profiles of social, political and economic organizations and of course also has an impact on education. The decentralization, personalization, increased flexibility, technologic convergence, and other effects of telematic networks call for both an extension of educational programs in the framework of lifelong learning programs and also require measures to overcome exclusion in the face of the new social, technologic and economic demands. Strategic learning, the teaching of comprehension, virtual collaborative groups, and teachers as facilitators - both in face to face and remote education - will help to develop autonomy, strengthen communication and technological abilities, and foster problem solving skills in order to make decisions and participate in the improvement of quality of life through flexible structures, open mentalities, and equitable ethical values. Within this framework, learning and teaching in the knowledge society of the twenty-first century will be conceived for personal self regulation and social self sustainable alternative development. The scenarios include creative competencies and flexible attitudes through the practice of comprehensive and critical reading and thinking, emotional education, free expression, contrasted transference into reality, and participation within diversity. The latter implies a respect to local identity to foster the search for universal peace, democratic coexistence and continuous improvement.
\end{abstract}

Key words: Strategic learning, Comprehensive teaching in the knowledge society. Self regulation. Self sustaintable social development.

\section{RESUMEN}

El proceso educativo en la sociedad del conocimiento del siglo XXI exige análisis muy complejos y transformativos en las propuestas de enseñanza y aprendizaje debido a la ubicua penetración de tecnología y especialmente de las tecnologías de la información y la comunicación - TICs - las que están presentes en todas las relaciones sociales. Ello contribuye al nuevo perfil social, político, cultural y económico de las organizaciones sociales en general con un impacto especial en la educación. La descentralización, personalización, flexibilidad, y convergencia tecnológica de las redes telemáticas ha generado nuevos desafíos no sélo a la extensión de toda clase de programas educativos en el marco del aprendizaje a lo largo de la vida ("lifelong learning programs") sino también a la superación de la exclusión frente a las nuevas demandas sociales, tecnológicas y económicas que aparecen. El aprendizaje estratégico, la enseñanza para la comprensión, y el trabajo en grupos colaborativos entre profesores y tutores grupos como facilitadores - presenciales o a distancia - deberán ser orientados a desarrollar autonomía, fortalecer la comunicación y las competencias tecnológicas y de resolución de problemas. El objectivoes propiciar toma de deci- 
siones maduras y participar en el mejoramiento de la calidad de vida a través de estructuras más flexibles, mentalidades abiertas y valores éticos equitativos. En este marco de referencia, el aprendizaje y la enseñanza para la sociedad del conocimiento del siglo XXI en sus propuestas educativas, tenderán a la autorregulación personal y al desarrollo social autosustentable. La inclusión de competencias creativas y actitudes flexibles a través de la práctica de la lectura comprensiva y del pensamiento critico en Internet, la educación emocional, el estímulo a la libre expresión, y la diversidad, transferencia a la realidad en términos de participación, respeto a la identidad local y la diversidad, deberá articularse con la búsqueda de la paz universal, la coexistencia democrática y el mejoramiento humano continuo.

Descriptores: Aprendizaje estratégico y enseñanza para la comprensión en la sociedad del conocimiento. Autorregulación personal. Desarrollo social autosustentable

\section{RÉSUMÉ}

Les processus de l'éducation dans la société du savoir au XXIe siècle nécessitent une analyse et une transformation très complexes à travers leurs propositions en matière d'apprentissage et d'enseignement. La pénétration omniprésente de la technologie et particulièrement de l'informatique concernant toute la relation humaine, contribue à de nouveaux profils culturels des organisations sociales, politiques et économiques, et surement à un impact sur l'éducation. La décentralisation, la personnalisation, la flexibilité, la convergence technologique etc... des réseaux télématiques sont un défi pour toute extension de programmes d'éducation dans le cadre des programmes d'apprentissage à longueur de vie (Lifelong Learning), mais aussi afin de surmonter l'exclusion face aux nouvelles exigences sociales, téchnologiques et économiques. L'apprentissage stratégique, l'enseignement pour la compréhension, les groupes de collaborateurs virtuels, enseignants, professeurs agissant comme guides-facilitateurs - face à face ou à distance - seront entraînés à aider à développer l'autonomie, à renforcer les habiletés en communication et en technologie, les habiletés à résoudre les problèmes et le reste en vue de prendre des décisions et de participer à améliorer la qualité de vie par le moyen de structures flexibles, de mentalités ouvertes et de valeurs étiques équitables. Dans ce cadre, l'apprentissage et l'enseignement dans la société du savoir au XXIe siècle dans toutes ses propositions éducatives sera conçu en vue de l'autorégulation personnelle et du développement social alternatif autodurable dans des scénarios qui incluent les compétences créatives et des attitudes flexibles par la pratique de la lecture et de la pensée compréhensives et critiques, l'éducation émotionnelle, l'expression libre de stimulus, et en vue d'un transfert résolu par le contraste avec la réalité et la participation au sein de la diversité en respectant l'identité locale dans une quête de paix universelle, de coexistence démocratique et d'amélioration continue.

Motes-Clés: L'apprentissage et l'enseignement dans la société du savoir au XXI siècle.

\section{Introduction}

$\mathrm{T}$ HE PURPOSE OF THIS CONTRIBUTION is to describe the educational processes within the twenty-first century's knowledge society in order to analyze its complex context of transformation and its impact on learning and teaching, especially considering the ubiquitous penetration of technology and the impact of technology on human relationships.

The main conclusion drawn by this paper is that decentralization, personalization, flexibility, telenologic convergence and other factors are features of the telematic networks of the knowledge society. These challenge not only the extension of educational programs within the life-long learning framework, but also are overcoming exclusion in the face of new social, telenologic, and economic demands. 
The steps which must be taken to reach the conclusion are to implement strategic learning, the teaching of comprehension, the utilization of virtual collaborative groups, and the training of teachers, professors, and tutors as facilitators for both face-to-face and remote online tutoring. These measures will aid students in developing autonomy, strengthening communication, mastering technological skills, and acquiring problem solving skills in order to make decisions and participate in the improvement of the quality of life through flexible thought structures, open mentalities, and ethical values.

In this way, learning and teaching in the knowledge society of the twenty-first century will be realized for personal self-regulation and sustainable social development in diverse scenarios. Such learning and teaching must include creative competencies and flexible attitudes through the practice of comprehensive and critical reading and thinking, emotional education, the stimulus of free expression, and contrasted transference into reality and dialogic participation within diversity together with respect to local identity toward a search for universal peace, democratic coexistence, and continuous improvement.

\section{What Kind of Knowledge Society?}

It is impossible within the limits of this paper to account for all the information society's factors. If we must characterize the technologic evolution, we must point to Information and Communication Technology with its accelerated pace as being responsible for the modification of the material and symbolic bases of society. One term used in the literature today is knowledge society that appears now to be more a utopia than a reality. The knowledge society supposes a new society with the creation and use of intensive technologies which result in a new, clean style of production, distribution, and utilization of products in a flexible approach. This society has resulted from historical evolution during the second half of the twentieth century, when society moved from an industrial base with smoking factories and the dirty post-industrial/mass media/consumer society to a new era based on the synergic exchange of information and knowledge. New qualifications are needed to respond to a world of continuous change, change which is coupled with optimism over opportunities and high investments in education, training, research, communication, innovation, and ICT. These have had a profound impact on communities, organizations, and individuals. The new realities have been faced which has given a sensation of change, maybe that beyond change itself because change always exists. The point is in the speed, multi-directionality, and meaning of the change.

Knowledge generation and information processing through the appearance of ICT have resulted in new conceptual constructions and neologisms within both the academic and socio-political frameworks. This impact has given a new kind of "energy" to all human activities in a ubiquitous technological paradigm that covers and is related to social, cultural, political, economic, and organizational factors and contexts. Work and production, home and consumption, commerce, entertainment, socialization, and data transmission among companies and organizations create rich informational fluxes that have impacts everywhere. To facilitate the transition to this society and in order to 
enhance protagonist minds and wills in people in these new environments, a "life-long learning society" needs to be pursued. Along with this, a framework of strategic teaching and learning processes establishes a new premise for the technologic mediation process: to teach the evaluation and criticism of information for its application toward the demand for social equity.

A new paradigm of "the life-long learning culture" is needed. In this proposal this means:

1. the recognition of the diversity of people, practices, knowledge, values, and social meanings in order to reflect and evaluate action before acting and in order to enhance learning to live together during a cultural change;

2. the overcoming of exclusion and the digital gap among people through training in the new productive activities based on telematic communication and knowledge which has been brought about by the introduction of ICT and its regulation in socio-political spaces;

3. the encouragement of protagonist anticipation and strong participation through cooperation, dialog, and empathy made sustainable by enhancing emotion and practicing education.

What kinds of disciplines are studying the information society? Although the information society is studied by all the sciences and technologies, mainly it is being researched by education sciences, social communication sciences, social psychology, cultural studies, cognitive science, sociology, and computer science. If we are truly concerned about developing pertinent socio-cultural proposals to know more - especially in South America - we must apply ICT in education by deepening the cultural production on the Internet and not just considering it a sophisticated technological artifact. (Castells 2002) This is so because we are moving toward a society of intangible products and services created by information and knowledge where richness lies in ideas. Within social constructivism, studies take into account the incidence of ICT in scientific activities, the dynamics of culture, social movements, the nature of identity, and economic development within a globalized world. Here the production, distribution, and consumption of material and symbolic services are organized and marketed for world consumption, stimulated by mass media and telematic channels.

The Internet as the net of nets plays a large role in general, especially for education. It is delimiting a new cultural space within the global culture and is redefining the previous industrial one by configuring different national and regional identities and cultures which today are saturated with transnational references. (Canclini 1999) states that our current culture, within an accelerated multiethnic and multicultural interdependence, is a mix of aspects of the postmodern condition through the impact of interaction given force by the speed of ICT. This presents paradoxes and contradictions which are seen in the transnationalization of symbolic fluxes, the appearance of new regimes of government and a redefinition of state-nation duties, and the multiplication of values and traditional conflicts among cultures and communities which defy the legitimation of global governance. 
As members of this new society with a new culture, we must decide what is appropriate in order to make the transition from the stage of data in the past toward information, knowledge, and comprehension, so that we will reach the future with wisdom.

To configure the knowledge society - which may take several generations - it will be necessary to rebuild mental and socio-cultural representations, to demystify false and utopian illusions, to overcome common sense through more rational, critical, and transformative frameworks, and to explore both the technologic potentialities and promises and its risks and limitations in order to take advantage of them and their potential enhancement of social strengths for a multi-identity.

In this way, the extension, intensity, speed, and impact of global flux, ICT interactions, and networks will oblige people and countries to reformulate the relationships among politics, economy, society, culture, and education. On the other hand, the structuring of telematic systems at the same time facilitates these processes and creates new environments. But this opportunity will exist only for those societies with access to IT and which can overcome economic, social, and other gaps. To accomplish this we must ratify values and wills to live in peace and global governance according to shared rules of coexistence.

So, the question is what kind of knowledge society are we building, or reaching, or moving toward? Although this society implies a socio-technologic transformation, each society throughout history has been a knowledge society. In every historical society information and knowledge were decisive in determining power, wealth, and social organization. It seems confusing to speak about the present to future knowledge society in a unique way. Consequently, we have to specify what kind of knowledge there was before, what there is now, and what is the desired configuration in each society. This will depend on cultural, economic, technologic, social, and political decisions and also contextualized needs.

And now the question arises, is the knowledge society a political-economic tool or simply an empty concept? It is very important to clarify this in order to analyze the knowledge society's genesis, development, and projections to education as a dependant variable - which is the main point of this discussion. To access information and its processing allows us to manage and rebuild this society and, even though it floods us with so much information, the mechanisms to access information are not exclusive of technologic ways. This means that every historical society is characterized by implementing strategies to choose, build, transmit, share, and recreate knowledge in order to contribute to the integration of peoples and allow them to function and be innovative. The challenge today is to explore high cognitive functions and solidarity values in order to promote equity of access to data and promote good judgement in "rational heads" (Morin 1999), to develop "intelligent minds" (Gardner 1992) or "symbolic analysts" (Reich 1993) who can transform, synthesize, and apply information and knowledge to solve problems with the highest responsibility.

But are there indeed new substantial tendencies or are they theoretic proposals? As was said above, each society has its knowledge and beliefs, procedures, artifacts, and values within their specific culture. These features are not mere standardized steps in western capitalism on a planetary dimension because the point is to recognize and respect 
their diversity. What role does ICT have in this context? What margin exists to appropriate technology in different socio-cultural contexts while respecting their diverse needs?

There are many questions and only a few answers for these new times in the twentyfirst century, including questions about the inherent challenges to education. Many constructive debates are needed about ICT toward what class or model of society each country or culture needs, likes, wants, should have and/or decides to build. If these debates do not take place, the danger lies in the "two speed society" or in fragmentation with the attendant social risks. This is true for more than the countries in South America.

\section{Features of the Knowledge Society}

To name only some of the complex features of our uncertain and chaotic times, the list includes digitalization, virtualization, cyberspace, networking through the ICT transversal, "prosumption" (production and consumption in the same protagonist, from Drucker), economic globalization and internationalization of markets and capital, new spaces for socio-politic participation, new models of organization for enterprise, industrial dislocation, the appearance of new tools of knowledge management which include those for both hardware and software, digital gaps, and threats against privacy through social control and cultural normalization. All of these have an impact on education and its teaching and learning concepts and practices.

In this twenty-first century information society, we are facing a new sociology in a non-linear interaction which is mediated by electronic artifacts, procedures, and sophisticated concepts and which point out contrasting cultural beliefs, thoughts, and minds. In focusing on this, the need for a technologic literacy of specific competencies becomes important, but not only to satisfy economic demands. This vision seeks to train qualified human resources for a strong technologic development which enhances creativity, autonomy, and logic, all parts of critical reasoning and problem solving skills. Incorporating ICT in education (in every way: e-learning courses, hypermedia, web-based proposals, and so forth) involves a daily socio/epistemological construction, despite the current uncertainty, insecurity, and world-wide violence. This reflection in everyday social practice cannot wait.

ICT in Universities, non-government organizations, companies, technologic networks, and so forth help in such enterprises mostly in the following sectors:

1. The current economic trend is e-economy which makes changes in the structure of work and in its organization by implementing the intensive production of knowledge generated from within the organization by trained people rather than from outside the organization. The challenge is to generate more commitment, dedication, and flexible attitudes than to receive vast qualities of information.

2. Social life appears in information networks and interrelationships (the global village) of multicultural fluxes and spaces of information, which is why there are significant modifications in learning and teaching in order to encourage intercultural communication skills and attitudes. This leads to changes in self-reliance 
and the development of skills in self-learning in order to speedily manage and distribute data. Autonomous but interdependent abilities are enhanced to recreate knowledge produced in virtual, collaborative, and distributed ways.

3.Life-ling learning involves the design of flexible and personalized opportunities for education and the extension of these in order to survive in a complex world where everyone will commit in a personal, collective, global learning process.

4. ICT must be taken into consideration because leaving ICT aside would be costly for each country. It would mean moving away from the current historiccultural times that advocate for more intelligence, awareness, and reciprocity among peoples, groups, organizations, and countries.

\section{Doubts of the Knowledge Society}

Presently some difficulties are worsening because of a global economy which poses the very real threat of outcomes such as inequity, insecurity, generalized violence, exclusion, and diverse ideological and religious fundamentalism. We can see that this challenge is faced not only by politicians and economists but mainly by social scientists, professors, and researchers who must reinterpret historic, geographic, philosophic, political, sociologic, economic, and cultural profiles related to programs in central countries as an option. People - students, women, youth, and so forth - in underdeveloped countries must have access to the delivery of ICT products so that their suffering is not increased by the consequences of the globalized movement.

The answer lies in building alternative proposals in a critically adaptative framework and including socio-technological advances which are produced in developed countries, not in order to create a direct or linear cultural transference in peripheral countries by adoption, but by adaptation. Not only should technologic features like more interactivity, connectivity, and non-linear hypermedia productions be taken into account for the design of educational mediations but also the contextualization in order to avoid serious risks of social normalization and cultural disciplining. (Rozak 1990)

Achieving a knowledge society involves achieving a deep change in mentalities more than just buying technical artifacts which are necessary but not definitive. It also involves develop the ability to adapt them in creative and equal proposals for diverse environments and groups, rather than adopting them without thought. Flexible education, training, and recycling programs for diverse social and cultural profiles will ease the way for people to enter this society.

From the vision of the global hypersociology and despite the inclusion of new groups, the migrations of peoples, the new ecological movements, and the impact of ICT as cultural relations and relationships, the world is divided and must be thought of "within reflexive action" because it is the local people who know and have to act, participate, produce, anticipate, and contrast. What makes a difference is what people do with what they know in their own situations. (Grulke 2001)

Therefore, it is important not to reproduce in an unreflective way the dominant discourse of the knowledge society as it is known in developed countries. Rather, within 
a framework of appropriate educational technology it is necessary to appropriate the concept of the knowledge society in order to respond to the socio-political conditions of these countries while looking toward an alternative construction of the ICT society. (Fainholc 1990) These new realities call for interdisciplinary approaches to study and research at university and government levels, for without these it will be impossible to improve our understanding of society and take the correct measures. "Those who don't plan with solid knowledge will become slaves of alien plans.” (Bunge 2004)

\section{What Does it Mean to Learn in the Knowledge Society?}

Castells (2001) in his work "The Rise of the Networked Society" underlines the skills or their lack of as the central point in order to control technology. In particular he wrote that technology is and has been decisive strategically in each historic time and has had a great influence in the transformation and destiny of society. ICT is a strategic tool in the twenty-first century, and much work is still needed to deepen our knowledge of ICT in order to articulate this technology into different learning paradigms. If this is not done, technology and its equipment and artifacts will only be incorporated into old, linear education models.

Within this context, the challenge is to produce, to re-elaborate, and to incorporate socio-cultural capital, called "habitus", (Bordieu 1991) as the "system of dispositions and generating and organizing principles of people, practices, and mental representations collectively orchestrated." In this case it is related to promoting and developing cultural practices within a habitus system, that has incorporated excluded groups into the new virtual territory of ICT as a way to slow down the growth of the technologic gap between rich and poor, northern and southern countries, regions, cities, and neighborhoods.

What does it mean to learn in the knowledge society? Learning could be defined as "increasing tacit knowledge which involves informal and experienced ways to do things which have been proven in everyday practices as successful techniques." They are also combined with the scientific knowledge, diverse procedures or routines, specific skills, creative developments, and so forth. that operate during long periods with formal and non-formal learning to produce diverse cultural results and impacts.

We do know that technology is a part of culture and each society in its time has had its specifically needed and desired technologies. From a formative point of view, technology is a dimension of communication taking shape in the interaction with the environment, a sort of "tool box" in the human mind. (Bruner 1997). This serves as "mind-ware" which is used to create and recreate hardware and software for the service of humans.

An "inclusive" knowledge society should have intelligent scenarios. By this is meant that it should have an inspired vision where the environment is the interface, because technology begins to be more and more invisible. In these scenarios, rather than connectivity with broadband to cover regions and nations with a view to connecting the 
majority of people online, a more desirable aspect is that of the intelligent environment. Here we can observe and promote two types of learning:

1. Generic, specific and transversal technologic competence, and

2. within these above, the training of cyberspace skills

Generic competencies can be considered those abilities, behaviors, and attitudes which relate to the dimensions of technologic knowledge production like information management skills (look for and evaluate, organize and maintain information systems, interpret and communicate with or without computers); development of systemic capture and comprehension (understand complex relationships, monitor systems, and correct performance); design and project mediated pedagogic proposals with materials and artifacts, simple and sophisticated, or electronic artifacts in schools and higher institutes of learning, open and distance learning groups; to plan, manage, and evaluate interpersonal relationships for tem work with cooperative activities; to transfer or practice abilities related to negotiation and leadership.

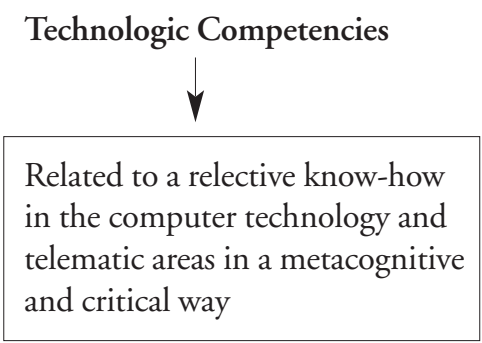

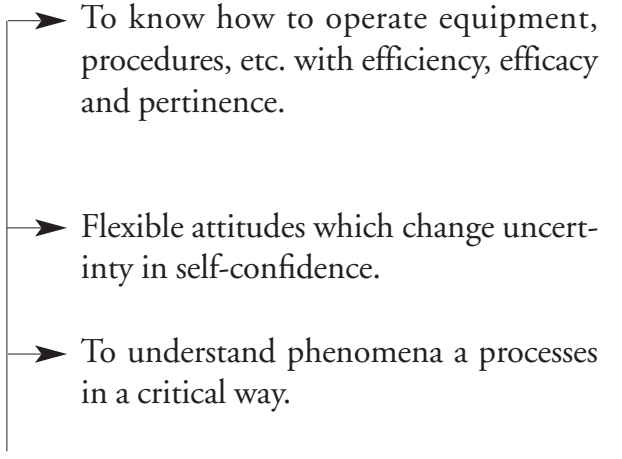

Specific competencies are those related to techniques linked directly to reflective and confronted actions in the practice of educational technology. These take into account design, production, implementation, evaluation, and improvement and research on systems. Also included are projects and programs, materials and resources, operations and activities for diverse media and educational environments, which operate face to face or at a distance, computer and telematic, and those which are easy to transfer to work contexts, such as the operation of designing navigation maps for multimedia materials to a different content, the development of technologic expertise with which to evaluate, maintain, select and combine technologies applicable to diverse tasks to oper- 
ate artifacts, graphic design, project formulating for centers of resources for learning in different public or private organizations.

Tranversal Competencies in the field of educational technology are related to the construction of concepts, the development of attitudes, and the engagement of methodological abilities with interdisciplinary areas such as artistic development, creative imagination, and resource management, that is, the distribution of time, money, material, and personnel. To respect multiculturalism, overcome sexism, encourage wise consumption, and to promote equality, peace, public health, non-alienated leisure, and human rights there are transversal contents to be selected for the development of competencies in didactic activities such as studying cases and working on problem solving.

Success in cyberspace requires many of the following skills presented below as a concept map. These are elements within technologic knowledge required for the knowledge society as tacit knowledge, as mentioned above. This knowledge involves informal and experienced ways of doing things in cyberspace which have been proven to be successful as everyday practices. Here ICT is combined with scientific knowledge, diverse procedures or routines, specific skills, and creative developments.

\section{Increasing Socialization Within ICT}

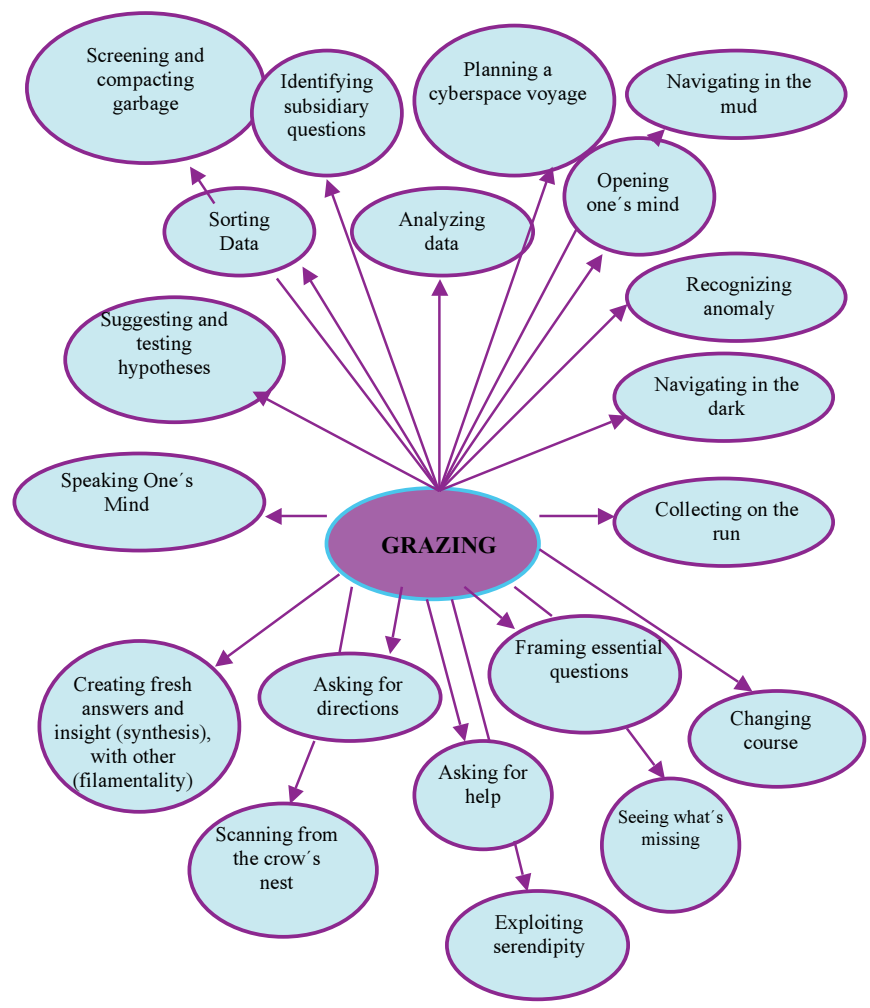

Jamie McKenzie: Special OnLine Version of Phi Delta Kappan article, September 1999, expanded by the author. 
In consequence, the task today is socialization within ICT in order to develop strategic learning. In this context the first priority is the professional training of faculty and teachers to enable them to train others in the technologic competencies listed above. But first they must teach themselves the new concepts and procedures in order to restructure their mentalities in light of changing demands: What is needed at work and in everyday life is a strategic way of solving problems gained through strategic learning. Strategic learning is related to inter and trans disciplinary concepts, intimately engaged with the epistemology of each and the mechanisms of personal metacognition. Strategic learning implies action which requires knowledge, power, and the will to learn about the learning process. (Pozo and Monero 2000) From this perspective, to be strategic is to make decisions in which interior motives, attitudes, concepts, and procedures (algorithmic or heuristic) are activated in the face of a problem situation. In other words, to learn strategically is to think and act beyond just applying technical procedures, no matter how successful they are.

From all the intervening variables, in order to develop strategic learning for an intelligent environment, peer interaction is central to consolidating a really cooperative and productive context through group interaction by

- facilitating shared problem solving where each person contributes in order to reach a common objective through essential contributions;

- developing social interaction skills linked to social perception and group comprehension, including taking into account the points of view of the others within the negotiation process of assuming and according roles and tasks;

- sharing the three main stages of the life group interaction within self regulation activities, such as planning, implementation, and evaluation. (Badia 2003)

If the driving force of the twenty-first century is ICT and the Internet, the learning process in this knowledge society becomes an activity, rather than a place, and will be conceived and encouraged only if designed for many different settings and for different processes. Within the limitations mentioned above, ICT educational programs will grow in several locations and many formats, including web based, e-learning, hypermedia/CBT courses, and so forth. So developing "communicative competencies" (Habermas 1989) and thinking abilities will tend to consolidate intellectual capital as the only competitive edge in the information society. The emphasis will be on discovering and solving problems, retrieving information, and focusing on processes and results rather than on time and will involve "opening minds" in order to build knowledge in networks by interacting and doing.

The skills students acquire about how to learn online through ICT are and will be the same skills they will need to prosper at workplaces in the twenty-first century. Knowledge workers and/or symbolic analysts are the workers needed in a knowledge society. (Reich 1993) There are two interrelated reasons for this

1) computer chips quadruple in power and speed every 12 - 18 months so that data has to be processed into information and replaced due to wear. (G. Moore, 1970) 
2) in order to analyze and evaluate the increasing volume of information as it is used and replaced at a faster and faster pace, sophisticated thought processes are needed to discriminate, compare, infer, explain, refuse, etc.

In this context students have to depend on self-discipline to develop, monitor, and improve skills, procedures, and understandings in face-to-face situations and through "learner management systems" software as well.

\section{What Does it Mean to Teach in the Knowledge Society?}

If the dominant feature in the knowledge society is the acceleration in the rhythm of creation, accumulation, and depreciation of knowledge as seen by the advance of innovation and the intensity of scientific and technologic progress, then teaching will result in the cultivation of socio-cognitive abilities, creativity, and invention in teachers and professors. This will involve overcoming anachronous teaching concepts still in place in schools, universities and centers of cultural diffusion. These were anchored in an old rationality belonging to the logic of Aristotle, to Cartesian methodological divisions, and to Newtonian determinism. These statements, typical of industrialism, are simple and rigid today and do not fit into the complex information society where information fluxes and networks have substantially modified the social and economic dynamic, that is, the management and administration of production and everyday life. Among the strategic recommendations for teaching in the knowledge society are

1. to value the knowledge capital of people and organizations;

2. to stimulate observation and the selection and/or combination of technologies for their implementation;

3. to formulate a shared vision;

4. to develop prospective analysis;

5. to promote and manage innovation;

6. to undertake innovative experiences;

7. to be aware of quality development;

8. to reinforce social cohesion with "scaffold" ideas

The concept of cognitive scaffolding for learning, speaking metaphorically, is a teaching structure like a temporal architectural aid. Vygotsky called it "the Proximal Development Zone" which supports the building while it is under construction. (Moll 1990, 1992) When the building can support itself, the scaffolding is withdrawn and similarly when people have acquired or developed skills and concepts the cognitive scaffolding is withdrawn. The concept of scaffolding can be found in some Internet proposals for instructional design, for example small groups, case studies, simulations, e-portfolios, weblogs, conferencing, chats, videoconferencing, webquests, and rotative leadership. Scaffolding in general will have the following characteristics

1. the reception of different sources of data, facts, and concepts when relevant information is extracted from the irrelevant action context; 
2. the transformation of information when it is necessary to understand, value, decide on, and integrate information;

3. the production of information when an original product is created with the acquired information;

4. the teaching process will be considered as scaffolding in the reception of information when teachers prepare and guide perceptions by helping to catch relevant aspects and by avoiding losing students in networks, the Internet, and so on; by interviewing experts to gather and compare specific information; by making glossaries if the vocabulary is unusual or unknown; in preparing chronologies both to give significance to diverse events and to understand them better; through guides which orient attention to important points and their relationships; by designing graphics and organizational structures with specific characteristics as aids in discriminating similarities and differences; by preparing checklists with which to evaluate Internet sites and Web pages in order to rate reliability; through the introduction of simulations which aid in generate ideas to use analogies to solve problems; and by demonstrating diverse logical arguments.

An effective pedagogy for the knowledge society in the twenty-first century implies an appropriation of virtual space and ICT tools for good instructional design in order to create an environment in which a majority of students - children, youth, or adults gladly learn. Some characteristics of this environment are

1. A diminished role for "the teacher" from "sage on the stage" to "guide on the side" and stimulation of protagonism in students who are doing most of the work. In this way they are engaged in aims, content, and activities. The more they do the more they will learn which in turn will increase the quality time spent in interacting with information and building knowledge.

2. Interactivity as the heart of effective learning, with students helping each other learn in real and virtual groups through peer assistance. This will involve educational activities with synchronic and asynchronous interactivity and participation in solving problems.

3. The enhancement of social presence as when participants in a real and online course present themselves as "real people" in various forms. This benefits the affective dimension which includes the expression of emotion, feelings, and moods; the interactive dimension where we can see evidence of reading, attending, understanding, thinking about other's responses, and so on; and the cohesion which is related to responses that build and sustain a sense of belonging, group commitment, and common goals and objectives.

An increased awareness of cognitive presence through introducing factual, conceptual, and theoretical knowledge into classroom discussions in, first, a "community of practice" and, later after training, becoming a "community of inquiry". A community of practice defines itself along the dimensions of "what it is about" and the joint enterprise is understood and continually renegotiated by its members. Its functions in mutual engagement bind members into a social entity and its capability is a result of a shared 
repertoire of communal resources (routines, sensibilities, artifacts, vocabulary) that members have developed over time. Communities of practice and inquiry are selforganizing systems that develop around subjects that matter to its members Guide presence is the facilitation and direction of a socio-cognitive progress in order to produce personal, meaningful, and - from an education point of view - worthwhile learning results. Collaborative group discussions add teaching presence by

- sharinfacilitating the discussion. This means setting the climate for learning;

- sharinidentifying areas of agreement and disagreement; prompting discussion from participants; seeking to reach consensus/understanding; encouraging, acknowledging, and reinforcing contributions; and assessing the effectiveness and pertinence of the pedagogic process.

- sharinutilizing direct instruction which includes introducing aims, contents, activities, and questions and focusing the discussion; summarizing the discussion and monitoring the process; injecting knowledge from diverse sources; and guiding and responding to diverse technical concerns.

\section{Education Conceived to Teach and Learn Toward Self-Sustainable Development Through Pertinent Abilities and Values}

Although it is difficult to predict the future, recent technologic advances show rapid evolution and present some trends which are not unidirectional. Economic and cultural developments at this time have acquired characteristics and patterns which have little in common with those of the previous decades. It would be wrong if all that was done was to graft more technology and ICT into the obsolete substratum of the former industrial society, or to elaborate new rules for information diffusion, or to put more computers in schools and universities. These are necessary but are insufficient in the face of the fastest and most sweeping social change in history. The main change, in my opinion, is linked to the nature of knowledge which penetrates all areas. In contraposition to the authority of books and scientists (whose roles are changing), the learning and knowledge interaction is being transferred to different and combined learning materials which reflect the pre-active planning, scaffolding, and monitoring of the interactive learning and the post active impacts in diverse social dimensions. So, technologic or electronic literacy in the information society draws on not only reading, computer writing, new ways of coding multimedia, and information through hypermedia discourses, but also cognitive and social skills, sensibilities, and cultural forms.

To look for a specific society's needs and characteristics is a challenge but a necessary one in order to convert the "informational movement" into a kind of sustainable and supported development, like a constant adaptation process of successive and unpredictable changes in today's complex world. There are main conditions toward a greater sustainability and viability of a holistic development where the field of education is dependent on macro areas. (di Castri 1998) These include local empowerment, con- 
nectivity among large system components, and the respect for economic, cultural, and environmental diversification. In this sense the new pillars of development are

1. caring for human dignity and culture specificity while rejecting segregation in the human condition;

2. the empowerment of local communities by accessing, online and just-in-time, important information through knowledge networks, in local languages and in bidirectional and horizontal ways in order to connect and integrate marginal or rural communities,

3. maintaining the natural and cultural patrimony centered in the people;

4. stimulating individual and organizational initiatives with accountability5. Continuous learning or life-long training through e-learning, virtual learning, distance learning, blended learning, etc.;

6. culture-driven development in order to strengthen a viable and competitive development by decentralized and self administrative processes;

7. local and global governance.

According to the above listed points, education in the twenty-first century, with its formative proposals in the construction of an appropriate knowledge society, means looking for

- life-long learning with social equity and with the intention of developing the human potential through continuous processes which stimulate and train people to acquire whole knowledge, values, the skills needed in life and the ability to apply these skills with self-confidence, creativity and enjoyment in every situation, role, and circumstance;

- flexible education distributed by ICT in a flexible organizational project, so that educational proposals are distributed through networks which enhance the autonomy and protagonism of participants such as leaders, administrators, professors and students, and the general public in informal programs such as those in libraries, museums, cooperative organizations, and so forth. Pedagogical activities, intentional and applicative ones, would be distributed through non-conventional and diverse information sources, read and simulated, towards a significant reconstruction of meanings by synchronic and asynchronous ICT interactivity;

- the training of teachers to overcome their "historical destiny" to be considered as one who deposits knowledge in students' brains when really their role has a complex nature which cannot be reduced to simple skills and abilities. Schon (1987) wrote that teachers' actions - and by extension the actions of tutors in distance and virtual learning programs - include their emission of authorized judgment and practical decisions in what are uncertain learning and teaching situations. It is valuable to recognize that such situations need flexibility more than recipes and student orientation and guidance more than prescriptions. (Schon 1987) Therefore it is important to be aware that the fundamental interpretative and recreative role of teachers is not to apply skills in a standardized fashion as a mere technician, but rather to recognize and respect differences and then 
select and combine resources and media, strategies and activities to match social needs and cultural profiles with ethical responsibility and formative care. This raises the matter of the teacher as a person and his or her intentions and training, or in other words, raises the matter of the need to achieve an equilibrium between person and professional life and expectations in her or her role. (Fullan and Hargreaves 1996)

- creativity which is the ability to produce something new, sensibly reasonable, and with vitality and logic by a person or group who look at ways to create new meaning. From a different focus we understand creativity as cognitive or rational, with a strong emphasis on verbal concepts and semantic associations, with which to interpret the products of thought and problem solving (Guiford 1967; Torrance 1977), and the situational focus which highlights the emotional and motivational nature of creative talent, and move toward the self-realization theories (Maslow 1959; Rogers 1980) and psychoanalytic and neopsychoanalitic ones. Many theorists, for example Stenberg and Lubart (1991), state that the creative person invests efforts in areas and problems where others are not interested or do not perceive them, giving place to results of great value.

How do we teach and learn in creative ways? What strategies and activities facilitate this type of learning? Collins and Berge (1996) suggest adopting computer mediated communication as a definition, including online communication between people and CBT (computer based teaching), as an online dialog in order to encourage social interaction which will contain elements of creativity. These have important consequences to professors and tutors who conceive their teaching in a creative, vital, and vocational dimension in order to help to give meaning to the enormous volume of information through the incorporation of ICT in teaching and learning in the knowledge society.

Comprehensive and critical reading in any kind of technologic media plus evaluation of the resources which people deal with in the interaction with social communication media (today mainly through the Internet) must be incorporated in order to move from the information society to a knowledge society. Critical reading is a technique which allows us to discover ideas in a text through careful, active, and reflective reading. It is also the process of making judgments in order to evaluate the pertinence of what is read. It is the practice of second and third readings leading to deconstruction, analysis, and evaluation in two senses

1. analyzing the symbolic code implicated, in this case of the Internet, by hypertextuality or non-linear and converge hypermedia, interactivity, and connectivity, and

2. deconstructing the hidden or implicit elements which appear "naturalized" in a message produced and distributed by a different support.

These mechanisms, which have to be taught, are engaged with critical thinking in the measure in which they simultaneously sharpen the higher thinking functions of the mind. The gist of being critical, of course, is not to criticize but to question and not to take what is read entirely at face value. Structure, purpose, audience, author (tone, style, level of information, and assumptions and if they are appropriate for the audience's specific needs), and the content of the source (to discriminate whether it contains facts, 
opinions, or propaganda) are important dimensions of analysis to protect against the intoxication of the enormous volume of actual data. (Fainholc 2004) Some keys techniques include not reading only or primarily for information and reading for ways of thinking about the subject matter. It is important in teaching and learning in the knowledge society to avoid approaching texts by asking, "What information can we get out of it?." Rather what should be asked is, "How does this text work? How is one argued? How is the evidence (facts, examples, etc.) used and interpreted? How does the text reach its conclusions?" Those learners who are good, autonomous readers and evaluators are more may need only a few directions in order to be successful in virtual or ICT learning.

\section{Emotional Education}

Every action takes place against an emotional backdrop. As a consequence, it is important first to look into what emotion is that is being felt to analyze the action. However, this is difficult to do because there is little "emotional education" (Casasus, 2004) in families nor is there in schools and universities. Our emotions are part of our minds and thoughts which unfold into the rational thought operating in lineal sequences and emotional thought which operating in networks supporting the first.

Emotions have become more important in the knowledge society workplace because employees increasingly work more with people than equipment. So it is that it has also become important for education to consider empathy, curiosity, confidence, and security that are the central variables to take into account. It is also important not to think of education in terms of more classes or course hours but to consider the emotional climate of real and virtual interaction, of collaborative relationships with colleagues in online seminars and chats, and of the relationship with the tutor. Taking these things into account, the design, practice, and evaluation of education are complex matters in the knowledge society

\section{To Participate Within Diversitiy to Encourage Expression}

Technologic media are not important for the delivery of the content alone but are intrinsic to the learning environment, along with student characteristics, instructional design, collaborative teaching strategies, and ITC communication and platform. (Johassen, Collis, Campbell, and Bannan-Haag 1995) Collaborative work online using ICT contributes to achieving professional levels in knowledge generation, in promoting initiative, in expressing creativity, and in facilitating critical thinking, and also to assisting users in building a learning community with common objects and one which reduces isolation.

\section{Global-Local Identity Within Universal Peace}

Which immediate agenda of the knowledge society challenges professors, researchers, and social scientists? To enhance "global" (global-local) identity within universal peace is an important topic to take into account in planning. Social computer science studies 
and evaluates the positive and negative causes and effects of the impact of technology on society and is configuring a new conceptual and methodological agenda which has great pertinence in the face of the globalized movements. These globalized movements, such as international terrorism and fundamentalism, have posed challenges to look for ways to encourage more open dialogues in global and local negotiations.

\section{Conclusion}

As a new scenario, the global society establishes a critical and necessary reform of mind, feelings, and actions in educational programs through the appropriation of technology and ICT in teaching and learning in order to develop diverse skills and capabilities within an ethical framework. These cannot be considered only as energy which generate and process information but, like the processes and products of socio-economic, historic-politic, and cultural contexts, these impact on the whole of human activities in the production of culture. Knowledge construction as a skill linked more to the transformation of information than to the repetition and distribution of it, establishes learning and teaching spaces with which to develop logic and critical and reflective reasoning which in the longer run will be instrumental in solving problems and improving the quality of life with equity.

\section{Note}

This paper has been revised and edited by Dr. Sandra Casey, Faculty of Education, Queen's University.

\section{Bibliography}

Aspin, D.; Chapman, J.; Hatton, M.; y Sawano, Y. (Eds.) 2001. International Handbook of Lifelong Learning, part one, volume 6. Netherlands: Kluwer Academic Publishers.

Badia, A. (Ed.) 2003. Actividades estratégicas de enseñanza y aprendizaje. Barcelona: Ediciones CEAC.

Bordieu, P. 1991. El sentido de la práctica. Madrid: Edit. Taurus.

Bruner, J. 1997. La educación, puerta de la cultura. Madrid: Edit. Visor.

Bunge, M. 2004. Mitos, hechos y rezones: cuatro estudios sociales". Buenos Aires: Edit. Sudamericana.

Canclini, N. 1999. Culturas en Globalización. Venezuela. Edit. Nueva Sociedad.

Casasus, J. 2004. "Las emociones en la educación: un nuevo punto de partida”. En XIV Congreso Mundial de Ciencias de la Educación: Educadores para una nueva Cultural. Facultad de Educación, Universidad Católica de Chile. Mayo 2004, Santiago de Chile.

Castells, M. 2001. La era de la información. La sociedad en red. México: Ed. Siglo XXI. Vol. I.

Castell, M. 2002. La dimensión cultural de Internet. Internet Interdisciplinary Institute (IN3) de la UOC Catalunya, España.

Collins, M.P. \& Berge, Z.L. 1996. Facilitating Interaction in Computer- Mediated Online Courses, [online]. Dirección URL: http://www.emoderators.com/moderators/flcc.html

Di Castri, F. 1998. El desarrollo en la Sociedad de la Información. http://www.gobernabilidad.cl/modules.php?name=News\&file=article\&sid=597 
Gardner, H. 1992. La mente no escolarizada. Buenos Aires: Edit. Paidós.

Fainholc, B. 1990. Tecnología Educativa Propia y Apropiada. Buenos Aires: Edit. Humanitas. Fainholc, B. 2004. Lectura crítica en Internet. Rosario, Argentina: Edit. Homo Sapiens. Fullan, M and Hargreaves, A. 1996. What's Worth Fighting For in Our Schools? New York: Teachers College Press.

Goleman, D. 1992. La Inteligencia Emocional. Buenos Aires: Editorial Javier Vergara,

GrulkeE, W. 2001. Ten Future Lessons. Madrid: Pearson Education, .

Guilford, J. P. 1967. The Nature of Human Intelligence. New York: McGraw-Hill.

Habermas, J. (1989): “Teoría de la acción comunicativa." Madrid: Editorial Taurus.

Jonassen, D., Collins, A., Campbell, J. \& Bannan-Haag, B. (1995). Constructivism and computer-mediated communication in distance education. The American Journal of Distance Education, 9: 7-26.

Maslow, A. (Ed.) 1959. New Knowledge in Human Values. New York: Harper.

Moll, L. 1990. Vigotsky's zone of proximal development: Rethinking its instructional implications. Infancia y Aprendizaje, No. 50-51: 157-168.

Moll, L. 1992. Vygotski y la Educación.Buenos Aires: Edit.. Aique.

Moore, G. (1970). "Cramming more components onto integrated circuits". [On line] URL $<\mathrm{ftp}$ ://download.intel.com/research/silicon/moorespaper.pdf

Morin, E. 1999. La Cabeza Bien Puesta. Edit. Buenos Aires: Nueva Visión.

Pozo, J. y Monero, C. 2000. El Aprendizaje Estratégico. Madrid. Edit. Santillana.

Reich, R. 1993. El Trabajo de las Naciones. Buenos Aires: Edit. Vergara: Pags 171 a 182 y 221 a 236

Rogers, C. 1980. Creatividad en la Educación. Buenos Aires: Paidos.

Roszak, T. 1990. El Culto a la Información. El Folklore de los Ordenadores y el Verdadero Arte de Pensar. Mexico: Edit. Grijalbo.

Schön, D. 1987. La Formación de Profesionales Reflexivos. Hacia un Nuevo Diseño de la Enseñanza y el Aprendizaje en las Profesiones. Barcelona: Edit. Paidós. MEC.

Stemberg, E. y Lubart, T. 1991. Creating Creative Minds. Washington: Edit. PHI Delta Kappa.

Torrance, E.P. 1977. Creativity in the Classroom. Washington, DC: National Education Association. 
106 Encounters/Encuentros/Rencontres 